\title{
The significance of health in the hierarchy of personal values among nurses
}

\section{Znaczenie zdrowia w hierarchii wartości osobistych pielęgniarek}

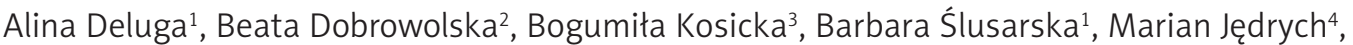 \\ Agnieszka Brzozowska ${ }^{4}$ \\ ${ }^{1}$ Department of Family Medicine and Community Nursing, Faculty of Health Sciences, Medical University of Lublin, Poland \\ Head of the Department: dr hab. n. o zdr. Barbara Ślusarska \\ 2Department of Development in Nursing, Faculty of Health Sciences, Medical University of Lublin, Poland \\ Head of the Department: prof. dr hab. n. med. Irena Wrońska \\ ${ }^{3}$ Department of Management in Nursing, Faculty of Health Sciences, Medical University of Lublin, Poland \\ Head of the Department: dr hab. n. med. Anna Ksykiewicz-Dorota, prof. nadzw. UM \\ ${ }^{4}$ Department of Information Technology and Medical Statistics with Remote Teaching Laboratory, Poland \\ Head of the Department: dr n. med. Bartłomiej Drop
}

Key words: personal values, nurses, socio-demographic variables.

Słowa kluczowe: pielęgniarki, wartości osobiste, zmienne socjodemograficzne.

\begin{abstract}
Introduction: Defining the idea of health and placing it within a personal hierarchy of values is often the foundation of choice of behaviors that determine a lifestyle.

Aim of the research: The main aim of this paper is to evaluate the significance of health in the hierarchy of nurses' personal values, including socio-demographic variables.

Material and methods: A total of 191 nurses, who were students of bridging studies of the first and second cycles at the Faculty of Health Sciences, the Medical University of Lublin, Poland and at the University of Business and Enterprise in Ostrowiec-Świętokrzyski, Poland, were included in the analysis. The study was conducted in 2014 and 2015. A standardized research tool, the personal values list (PVL) of Z. Juczyński was applied.

Results: The results of the study show that for the nurses, the most important aspects of happiness that define life satisfaction are "successful family life" (3.83 points), "good health" (3.55), and "favorite profession or work" (2.05). Personal values that are evaluated as highest by the respondents are "good health, physical, and mental fitness" (3.77 points), "love and friendship" (3.55) and, less commonly, "knowledge and wisdom" (1.75). The respondents of the eldest age group (above forty), had a tendency to value "good health, physical, and mental fitness" significantly higher in terms of personal value ( $p=0.0007)$, in comparison with the respondents of the younger age groups, for whom "intelligence and mental acuity" is more important $(p=0.06)$.

Conclusions: Health constitutes the highest value in the hierarchy of personal values indicated by the nurses and significantly conditions their satisfaction with life. Socio-demographic variables such as age, education, marital status, place of residence, and workplace influence the rank of health in the system of values for the surveyed nurses.
\end{abstract}

\section{Streszczenie}

Wprowadzenie: Zdefiniowanie pojęcia „zdrowie” oraz umiejscowienie go w osobistej hierarchii wartości stanowi często podstawę wyboru zachowań zdrowotnych będących składową stylu życia człowieka.

Cel pracy: Celem pracy jest ocena znaczenia przypisywanemu zdrowiu w hierarchii wartości osobistych pielęgniarek z uwzględnieniem zmiennych społeczno-demograficznych.

Materiał i metody: Badania przeprowadzono w 2014 r. i 2015 r. Objęto nimi 191 pielęgniarek, które były studentkami pomostowych studiów licencjackich oraz studiów magisterskich na Wydziale Nauk o Zdrowiu w Lublinie i w Wyższej Szkole Biznesu i Przedsiębiorczości w Ostrowcu Świętokrzyskim. Do zebrania materiału użyto standaryzowanego narzędzia badawczego LWO (Lista Wartości Osobistych), autorstwa Z. Juczyńskiego.

Wyniki: Przeprowadzone badania wykazały, że dla pielęgniarek najważniejszymi symbolami szczęścia, które warunkują zadowolenie z życia, są: „udane życie rodzinne” (3,83 pkt), „dobre zdrowie” (3,55 pkt) i „wykonywanie ulubionej pracy, zawodu” (2,05 pkt). Z wartości osobistych najwyższej cenione przez ankietowanych są: „dobre zdrowie, sprawność fizyczna 
i psychiczna” (3,77 pkt), „miłość, przyjaźń” (3,55 pkt) oraz rzadziej „wiedza, mądrość” (1,75 pkt). Respondenci z najstarszej grupy wiekowej (powyżej 40 lat) istotnie wyżej jako wartość osobistą cenią sobie „dobre zdrowie, sprawność fizyczna i psychiczną" niż badani z młodszych grup wiekowych.

Wnioski: Zdrowie stanowi najwyżej cenioną wartość w hierarchii wartości osobistych pielęgniarki i istotnie warunkuje ich zadowolenie z życia. Na pozycję zdrowia w systemie wartości badanych znaczący wpływ mają zmienne społeczno-demograficzne.

\section{Introduction}

The definition of the concept of "health" and placing it within a personal hierarchy of values is often the basis for choosing health-oriented behaviors as a part of a human lifestyle. It appears that the value attached to health is a factor that significantly mobilizes pro-health behavior [1]. As a result, health-related ideas express the degree of interest in one's own health, along with willingness to take health-favoring actions [2]. As shown by the research, adults who are convinced they can personally influence their health, tend to manifest more behaviors promoting maintenance and amelioration of health [3]. According to WHO's Health for All strategy, health is a value that enables humans or societies to satisfy their needs and aspirations, and to protect and shape the local environment. Health is also a resource for the society, one that ensures its social and economic development while helping achieve a better quality of life $[4,5]$. Health is one of the essential values that ranks high in individual and societal hierarchy of values [6]. It is an important decision-making element, which influence the choice of behaviors that shape the individual's lifestyle $[7,8]$. The assessment of the value of health differs depending on the context in which such evaluation is made and instrument used. The situation of health within the hierarchy-of-values system is conditional with various factors such as culture, sex, age, social position, educational background, domicile, and social awareness (as being significantly influenced by education and promotion of health) [9].

Health is an important value in the axiological system of medical professions, including nursing [10]. In addition, it is often stressed that nurses form a professional group with a potential to significantly influence health-oriented attitudes in the society [11-13]. Hence, investigating the rank assigned to nurses regarding health, and the placement of health within their personal hierarchy of values seems legitimate. In Polish scientific literature, there have been few reports published on how health is valued among nurses and in what ways it is perceived [14-16]. In turn, studies on the hierarchy of values among nurses or nursing students, indicating the position they tend to attribute to health as a part of their hierarchy of values, are rather rare [17]. International research lean towards focusing on analyzing the axiological system followed by nurses, based on the profession they perform and related decision-making process [18]. Therefore, our study emphases the importance attributed to health as a part of the hierarchy of nurses' personal values, taking into account socio-demographic variables.

\section{Material and methods}

The study was conducted in 2014 and 2015. It included over 200 nurses who were students of bridging studies of Nursing of the first cycle at the Faculty of Health Sciences in Lublin, Poland, and studies of the second cycle at the University of Business and Enterprise in Ostrowiec-Świętokrzyski, Poland. A total of 191 properly filled-in questionnaires (95.5\% of all the submitted) were qualified and used in the subsequent stages of the research process.

A standardized study tool referred as the list of personal values (LPV) by Z. Juczyński [3] was applied. The LPV is divided into two parts. The first part contains nine symbols of happiness that express a variety of forms of human values, and the second part includes ten categories of personal values. The latter contains health identified as physical and mental fitness. Reliability of LPV for both parts of the tool is 0.78 and 0.76 (test-retest), and the theoretical relevance is 0.74 [3]. In the first part of the tool, respondents were asked to answer the question: "What determines personal happiness?" by selecting 5 out of 9 presented symbols of happiness. Then, they had to organize their chosen symbols of happiness by their importance, by assigning 5 points to the most important symbol to 1 point for the least important. In the second part of the survey, respondents were asked to select five most significant personal values from 10 given in a tool and arrange them by importance, giving points from 5 to 1 ( 5 for the most important, and 1 for the least important). Symbols of happiness and personal values, which have not been selected were assigned in the statistical analysis with the value " 0 ". Points assigned to "health" reflects the value given to this category in the context of other personal values and personal goods [3]. Demographic questions have been added, which refer to age, sex, marital status, place of residence, vocational education and post-graduate education, job seniority/work experience, workplace, etc.

The research was conducted in accordance with the Helsinki Declaration. Each respondent was informed about the purpose of the study and assured that the study process was completely voluntary and anonymous. The data collected was anonymous, 
Table 1. List of personal values - symbols of personal happiness: average weights and distributions of ranks (in \%)

\begin{tabular}{|c|c|c|c|c|c|c|c|c|}
\hline \multirow[t]{2}{*}{ Symbols of happiness } & \multirow{2}{*}{$\begin{array}{l}\text { Average } \\
\text { weight }\end{array}$} & \multirow{2}{*}{$\begin{array}{l}\text { Rank of symbols } \\
\text { of happiness } \\
\text { in the list } \\
\text { of } 9 \text { symbols }\end{array}$} & \multicolumn{5}{|c|}{ Ranks (categories opted for, \%) } & \multirow{2}{*}{$\begin{array}{c}\text { No option } \\
\text { selected }\end{array}$} \\
\hline & & & 1 & 2 & 3 & 4 & 5 & \\
\hline $\begin{array}{l}\text { Considerable group } \\
\text { of friends }\end{array}$ & 1.06 & 6 & 12.6 & 12.6 & 6.3 & 8.4 & 3.1 & 57.1 \\
\hline Successful family life & 3.83 & 1 & 6.8 & 9.4 & 4.2 & 29.3 & 45.5 & 4.7 \\
\hline $\begin{array}{l}\text { Favorite job/ } \\
\text { work performed }\end{array}$ & 2.05 & 3 & 13.1 & 23.0 & 29.8 & 12.0 & 1.6 & 20.4 \\
\hline $\begin{array}{l}\text { Achievements in } \\
\text { education/work }\end{array}$ & 0.97 & 7 & 12.6 & 8.4 & 7.3 & 6.3 & 4.2 & 61.3 \\
\hline Good health & 3.55 & 2 & 7.9 & 9.4 & 11.5 & 28.3 & 36.1 & 6.8 \\
\hline Being needed by others & 1.39 & 5 & 12.0 & 20.4 & 17.3 & 7.3 & 1.0 & 41.9 \\
\hline Good material conditions & 1.48 & 4 & 20.4 & 12.0 & 20.9 & 6.3 & 3.1 & 37.2 \\
\hline $\begin{array}{l}\text { Adventurous life } \\
\text { (journeys, etc.) }\end{array}$ & 0.57 & 8 & 14.1 & 4.2 & 1.6 & 2.1 & 4.2 & 73.8 \\
\hline Fame/popularity & 0.05 & 9 & 0.5 & 0.5 & 1.0 & 0.0 & 0.0 & 97.9 \\
\hline
\end{tabular}

and the participants were offered the option to withdraw their consent to participate in the study at any time.

The values of the parameters analyzed have been characterized in terms of number and percentage as well as the average value and median. For the measurable features, the normality of the distribution of the parameters has been estimated using the Shapiro-Wilk W-test. For the continuous variables, the differences between the two groups have been evaluated with use of Mann-Whitney's U-test, whilst the Kruskal-Wallis test has been used for several groups. In the evaluation of the relation between the variables, Spearman's correlation was used. A 5\% non-sequitur and the related significance level of $p<0.05$ was assumed. The statistical study was supported by the STATISTICA 12.0 (StatSoft, Poland) software.

\section{Characteristics of the respondents}

Among the 191 nurses surveyed, females accounted for $95.3 \%$, whereas $4.7 \%$ were males. The respondents were aged $22-47$, with the average age of 32.4 \pm 9.2 years. The largest group of the respondents was $41.4 \%(n=79)$ consisted of young individuals aged 25 or below, $33 \%$ of the respondents $(n=63)$ were $26-40$ of age, while $25.7 \%(n=49)$ were more than 40 years old. $50.3 \%$ of the study group were married. Most of the respondents (41.2\%) were rural dwellers. Towns with a population below 20,000 were the domicile of $19.2 \%$ of the questioned, those up to 100,000 - 23.6\%, and above 100,000 - 15.7\%. As far as educational background was concerned, $50.8 \%$ were gradu- ates of five-year Medical Secondary School or two-year Medical Vocational College and students of bridging first cycle studies of Nursing. Bachelors constituted $15.2 \%$ of the respondents, and $9.4 \%$ were Masters of other than medical studies. $24.6 \%$ of the answerers were the students of the second cycle studies. Almost half of the respondents (49.7\%) had additional qualifications (specialized courses, trainings, etc.). The average seniority among those employed was 4.4 \pm 2.3 years (several months to seven years). Furthermore, $24.6 \%$ of the surveyed students were working at medical wards, $20.9 \%$ at surgical wards, and over $54.5 \%$ were employed in other places or studied.

\section{Results}

The hierarchy of the symbols of happiness among the nurses

As the first step, the hierarchy of the "symbols of happiness" expressing the manifestations of human values was determined. Analysis of the collected data has shown that, according to the nurses surveyed, the major symbols conditioning satisfaction with life included: "successful family life", which accounted for 3.83 points (against the matrix of $0-5$ pts.), "good health" (3.55), "favorite profession/work performed" (2.05), and less frequently chosen "good material conditions" (1.48). Of the remaining symbols, "adventurous life (traveling, etc.)" and "fame/popularity" have been ranked the lowest (Table 1).

It has been proved that for married nurses and nurses having children, as compared to single ones and 
Table 2. Correlation of ranks of the symbols of happiness to job seniority of respondents

\begin{tabular}{|lcc|}
\hline Symbols of happiness & $R$ & $p$ \\
Considerable group of friends & 0.15 & $0.04^{*}$ \\
Successful family life & -0.04 & 0.56 \\
Performance of a favorite job or work & -0.03 & 0.65 \\
Achievements in education/work & -0.06 & 0.46 \\
Good health & 0.04 & 0.63 \\
Being needed by others & 0.10 & 0.16 \\
Good material conditions & -0.06 & 0.40 \\
Adventurous life (journeys, etc.) & -0.05 & 0.49 \\
Fame/popularity & -0.12 & 0.10 \\
\hline
\end{tabular}

$R$-Spearman correlation coefficient; ${ }^{*} p<0.05$

Table 3. List of personal values - categories of personal values: average weights and distributions of ranks (in \%)

\begin{tabular}{|c|c|c|c|c|c|c|c|c|}
\hline \multirow{2}{*}{$\begin{array}{l}\text { Categories } \\
\text { of personal values }\end{array}$} & \multirow{2}{*}{$\begin{array}{l}\text { Average } \\
\text { weight }\end{array}$} & \multirow{2}{*}{$\begin{array}{l}\text { Rank of personal } \\
\text { values in the list } \\
\text { of } 10 \text { values }\end{array}$} & \multicolumn{5}{|c|}{ Ranks (categories opted for, \%) } & \multirow{2}{*}{$\frac{\text { No option selected }}{0}$} \\
\hline & & & 1 & 2 & 3 & 4 & 5 & \\
\hline Love/friendship & 3.55 & 2 & 12.6 & 5.8 & 7.3 & 28.8 & 38.7 & 6.8 \\
\hline $\begin{array}{l}\text { Good health; } \\
\text { physical/mental } \\
\text { fitness }\end{array}$ & 3.77 & 1 & 8.4 & 6.8 & 5.8 & 28.8 & 44.5 & 5.8 \\
\hline $\begin{array}{l}\text { Sense of humor, } \\
\text { liveliness/wittiness }\end{array}$ & 0.60 & 9 & 5.2 & 8.9 & 6.8 & 1.6 & 2.1 & 75.4 \\
\hline $\begin{array}{l}\text { Intelligence/ } \\
\text { mental acuity }\end{array}$ & 1.37 & 5 & 7.3 & 18.8 & 14.1 & 10.5 & 1.6 & 47.6 \\
\hline Knowledge/wisdom & 1.75 & 3 & 9.4 & 18.3 & 25.7 & 10.5 & 2.1 & 34.0 \\
\hline Joy/satisfaction & 1.60 & 4 & 16.2 & 18.8 & 23.0 & 7.3 & 1.6 & 33.0 \\
\hline $\begin{array}{l}\text { Courage, } \\
\text { resoluteness }\end{array}$ & 0.87 & 6 & 12.6 & 8.4 & 6.8 & 4.7 & 3.7 & 63.9 \\
\hline Kindness/gentleness & 0.78 & 7 & 15.7 & 7.3 & 6.8 & 4.2 & 2.1 & 63.9 \\
\hline $\begin{array}{l}\text { Nice/beautiful } \\
\text { appearance }\end{array}$ & 0.26 & 10 & 7.9 & 2.6 & 1.0 & 1.0 & 1.0 & 86.4 \\
\hline Wealth, fortune & 0.64 & 8 & 14.8 & 6.2 & 2.1 & 3.7 & 3.3 & 70.1 \\
\hline
\end{tabular}

without children, "successful family life" was assigned a significantly higher rank among symbols of happiness $(p=0.01)$, along with "good health" $(p=0.06)$, which proves close to significant. For the unmarried and childless respondents, "adventurous life (traveling, etc.)" was ranked significantly higher $(p=0.05)$. Moreover, it has been found that for the nurses working elsewhere than in a hospital and/or studying, the "considerable group of friends" symbol was of a significantly higher rank $(p=0.02)$ and importance, with growing job seniority $(R=15)$ (Table 2$)$.
It has been found that for the respondents aged up to 25 , the symbol "successful family life" was of a significantly higher rank compared to the respondents aged 26-40 and over 40 ( $p=0.02$ ). Differences close to significant have been demonstrated between the age groups; as far as the assessment of the "good material conditions" was concerned ( $p=0.06)$, the symbol was ranked higher among the younger part of the cohort. No significant differences have been found in the importance rating of the other symbols of happiness $(p>0.05)$. 


\section{List of the nurses' personal values}

Evaluation of personal values was the subsequent stage in the statistical analysis. The nurses have assigned the highest importance to "good health, physical, and mental fitness" (score, 3.77) and "love/ friendship" (3.55), "knowledge/wisdom” (1.75), "joy/ satisfaction" (1.60), and "perceptiveness/capacity of mind" (1.37) were less frequently opted for. The values described as "wealth and fortune" and "nice appearance" were ranked as the lowest (Table 3).

The research has shown that for the nurses who are married and with children, compared to the single (unmarried) respondents, "good health and physical/mental fitness" plays a significantly higher role among personal values ( $p=0.0003)$, likewise "knowledge/wisdom" ( $p=0.05)$ symbol. For the childless respondents, "perceptiveness/capacity of mind" has a significantly higher rank $(p=0.05)$. Further statistical analysis has showed that for the interviewed students inhabiting average-sized or small towns, or rural areas, "good health and physical/mental fitness" constitutes a significantly higher value $(p=0.003)$, along with "kindness/gentleness" ( $p=0.02)$, as compared to large city dwellers. The respondents of the eldest age group (over 40) consider "good health and physical/mental fitness" to be a personal value of importance (and of a significantly higher rank) compared to those of the younger groups $(p=0.0007)$. The respondents aged up to twenty-five, evaluated "intelligence and mental acuity" somewhat higher, as compared to those of the elder age groups $(p=0.06)$. It has been found that the surveyed with a higher (tertiary) educational background find "good health and physical/mental fitness" significantly more important than those with higher (secondary) education or those studying ( $p=0.03$ ). The nurses employed in medical wards attributed a significantly higher rank to "nice/beautiful appearance", compared to those surveyed from surgical wards $(p=0.04)$. Furthermore, it has been found that for the nurses working in medical wards and surgical wards, "good health and physical/mental fitness" ranks slightly higher compared to the respondents employed outside hospitals $(p=0.06)$. No significant differences have been found when it comes to the rating of the importance of the other personal values $(p>0.05)$.

\section{Discussion}

The study required to analyze the symbols of health and personal values with regard to their importance or significance for the surveyed nurses, with a particular focus on health as a part of the hierarchy of values.

The results of the research conducted among adult individuals have shown that health continues to be ranked high in the hierarchy of the nation's values.
Based on the study carried out in 2004 by the Public Opinion Research Centre (CBOS) [19], health (one's own and the family's) is of importance to all the respondents. A significant majority of the surveyed believed that good health is an essential value. Of the other indicated values considered important to the respondents is "successful family life" as well as "love and friendship" (both $97 \%$ of indications). A "social diagnosis" study conducted in 2005 confirmed that health is the pre-condition for a felicitous and successful life (first place for 65\% surveyed) [20]. Another CBOS study, the Health as a Value conducted in 2007 [21], showed that health ranks among the fundamental assets highly valued by the society. Preservation of good health, as one of the major values of daily life, was pointed out by less than threefifths (59\%) of the respondents. Only family happiness was valued higher (76\% of indications). A CBOS 2013 study, the Values and Standards, emphasizes that as from 2005, the hierarchy of values respected by Poles has remained mostly stable. Pointed out by as many as $82 \%$ surveyed, family happiness ranks highest throughout. Additionally, with $74 \%$ indications, health comes a close second among the nation's dearest values. Less, but still important were honesty and employment/professional career $(26 \%$ and $21 \%$, respectively) [6]. A public opinion research of 2014 on the components of successful life ("what one needs to have an enjoyable life") showed that slightly less than a half of the respondents (49\%) consider health as the major element of a successful life. Somewhat smaller group (46\%) consisted of individuals for whom money, ensuring wealth, and affluence are important. Over a fourth of the respondents (29\%) consider having an appropriate job and employment a priority. In turn, family (and children) as an element indispensable for an enjoyable life, is of importance to every fifth Pole (22\%) [22].

The outcome of this study is close to that of the nationwide research, as it shows that out of the symbols of happiness pre-conditioning satisfaction with life, nurses tend to attach priority to a successful family life, good health, and favorite profession or work. The personal values they rank highest include good health, which manifests itself in physical and mental fitness as well as love and friendship. Research conducted by Ślusarska et al. [17] in a group of 200 nurses using the LPV scale has shown that in terms of personal values, the most appreciated by nurses are: good health, physical and mental fitness, love and friendship, knowledge and wisdom, intelligence and mental acuity, joy and satisfaction. Similar data was obtained by Lewicka et al. [23] in a group of nursing and midwifery students. A Spanish study conducted with a group of 589 nurses and 2,295 students of nursing has shown that health ranks fifth among the values advocated by working nurses, and third with nurs- 
ing students [18]. Different results had obtained Rassin [24] in the study on personal and professional values among Israeli nurses, for whom values such as respect for personal dignity, altruism and trust, honesty, responsibility and reliability were indicated as a manifestation of motivation and personal attitude, influencing the realization of the professional role.

As it turns out, the hierarchy of personal values abide by nurses is significantly dominated by health, which is described in terms of physical and mental fitness. Giving the highest rank to health over the other personal values seems to result from the type of work they perform, including witnessing perturbations in human health and related problems in fulfilling a number of other values being of importance to every human being.

\section{Conclusions}

Health is ranked highest in the hierarchy of personal values of the surveyed and proves to significantly precondition their satisfaction with life. The position of health in the nurses' hierarchy of values changes according to the socio-demographic features of the respondents. The nurses of the elder age groups, with higher education, married and having children, inhabiting small towns or rural areas, assign a higher rank to health compared to other values of personal hierarchy. The variable related to the workplace diversifies the rank attached to health by the surveyed to a slight degree. Health tends to be ranked higher by nurses employed in hospitals, compared to those working in other institutions.

\section{Conflict of interest}

The authors declare no conflict of interest.

\section{References}

1. Majchrowska A. Zdrowie jako wartość. In: Elementy socjologii dla pielęgniarek. Baranowicz I, Majchrowska A, Kwaczyńska-Butrym Z (eds.). Czelej, Lublin 2000; 122-125.

2. Heszen-Niejodek I. Psychologiczne problemy chorych somatycznie In: Psychologia. Podręcznik akademicki. Strelau J (ed.). Gdańskie Wydawnictwo Psychologiczne, Gdańsk 2000; 513-531.

3. Juczyński Z. Narzędzia pomiaru w promocji i psychologii zdrowia. PTPPTP, Warszawa 2001.

4. Investing in health. Commission staff working document. Social investment package. February 2013. Available at: http://ec.europa.eu/health/strategy/docs/swd_investing in health en.pdf.

5. Tuszyńska-Bogucka V, Bogucka J. Zdrowie w hierarchii wartości. Annales UMCS 2005; 60: 91-94.

6. Boguszewski R. Wartości i normy. Komunikat z badań CBOS, BS/111/2013. Available at: http://www.cbos.pl/SPISKOM.POL/2013/K_111_13.PDF.

7. Malik M, Zarzycka D, Iłżecka J, Jarosz M. Wartość zdrowia jako czynnik motywacyjny do działań prozdrowotnych. Zdr Publ 2009; 119: 33-39.
8. Puchalski K. Psychospołeczne problemy zdrowia i choroby. In: Zdrowie publiczne. Wybrane zagadnienia. Puchalski K (ed.). Szkoła Zdrowia Publicznego CMPK, Warszawa 2011; 161-171.

9. Kijo P. Kultura zdrowotna w kontekście programowych zmian w edukacji szkolnej (reformy programowej 2009 roku). Kultura i Wychowanie 2011; 1: 213-226.

10. Marcum JA. An introductory philosophy of medicine. Humanizing modern medicine. Springer, Dordrecht 2008.

11. Povlsen L, Borup IK. Holism in nursing and health promotion: distinct or related perspectives? - a literature review. Scand J Sci 2011; 25: 798-805.

12. Kemppainen V, Tossavainen $\mathrm{K}$, Turunen $\mathrm{H}$. Nurses' roles in health promotion practice: an integrative review. Health Promot Int 2012; 10: 1-12.

13. Sturm BA, Dellert JC. Exploring nurses' personal dignity, global self-esteem and work satisfaction. Nurs Ethis 2016; 23: 384-400.

14. Naszydłowska E, Krawczyńska J, Kozieł D, Czerwiak G, Trawczyńska M. Wartościowanie zdrowia a zachowania promujące zdrowie studentów. Annales UMCS 2005; 60, suppl. 16: 62-66.

15. Lewko J, Łubińska M, Sierakowska MH, et al. Definiowanie pojęcia zdrowie przez pielęgniarki. Probl Pielęg 2006; 1-2: 127-131.

16. Ździebło K, Michalska M, Krawczyńska J, et al. Pojęcie zdrowia w opinii pielęgniarek studiujących na studiach licencjackich-pomostowych. Stud Med 2009; 14: 27-32.

17. Ślusarska B, Barczak S, Zarzycka D, Dobrowolska B, Cuber T. Znaczenie wartości osobistych i symboli szczęścia wśród pielęgniarek aktywnych zawodowo. Probl Pielęg 2011; 19: 219-227.

18. Jiménez-López FR, Roales-Nieto JG, Seco GV, Preciado J. Values in nursing students and professionals: an exploratory comparative study. Nurs Ethics 2016; 23: 79-91.

19. Wenzel M. Wartości życiowe. Komunikat z badań CBOS, BS/98/2004. Available at: http://www.cbos.pl/SPISKOM. POL/2004/K_098_04.PDF.

20. Czapiński J. Cechy osobowości i styl życia. In: Diagnoza społeczna. Warunki i jakość życia Polaków. Czapiński J, Panek T (eds.). VIZJA PRESS \& IT, Warszawa 2005; 150-163.

21. Boguszewski R. Zdrowie i zdrowy styl życia w Polsce. Komunikat $\mathrm{z}$ badań CBOS, BS/138/2007. Available at: http:// www.prawapacjenta.eu/var/media/File/K138_07_zdrowieizdrowystylzyciawPolsce.pdf

22. Boguszewski R. Co stanowi o udanym życiu? Komunikat z badań CBOS NR/167/2014. Available at: http://www. cbos.pl/SPISKOM.POL/2014/K_167_14.PDF

23. Lewicka $M$, Dzierżak A, Sulima $\bar{M}$. Health as a value in the opinion of students of nursing and midwifery. JPHNMR 2013; 4: 22-28.

24. Rassin M. Nurses' professional and personal values. Nurs Ethics 2008; 15: 614-630.

\section{Address for correspondence:}

\section{dr Anna Deluga}

Zakład Medycyny Rodzinnej i Pielęgniarstwa Środowiskowego

Uniwersytet Medyczny w Lublinie

4/6 Staszica St

20-081 Lublin, Poland

Phone: +48506 564609

Email: alina_deluga@poczta.onet.pl 